\title{
Extensive dissolution of live pteropods in the Southern Ocean
}

Bednaršek $\mathrm{N}_{1}$, Tarling $\mathrm{GA}_{1}$ *, Bakker DCE $\mathrm{D}_{2}$, Fielding $\mathrm{S}_{1}$, Jones $\mathrm{EM}_{3}$, Venables $\mathrm{HJ}_{1}$, Ward $\mathrm{P}_{1}$, Kuzirian $\mathrm{A}_{4}$, Lézé $\mathrm{B}_{2}$, Feely RA $\mathrm{A}_{5}$, Murphy EJ $\mathrm{J}_{1}$

*corresponding author: gant@bas.ac.uk

1. British Antarctic Survey, Natural Environment Research Council, Madingley Rd, Cambridge, CB3 0ET, UK

2. School of Environmental Sciences, University of East Anglia, Norwich Research Park, Norwich NR4 7TJ, UK

3. Royal Netherlands Institute for Sea Research, P.O. Box 59, 1790 AB Den Burg, Texel, The Netherlands

4. Department of Geology and Geophysics, Woods Hole Oceanographic Institution, Woods Hole, Massachusetts, USA

5. NOAA, Pacific Marine Environm Lab, Seattle, WA 98115 USA

Please note that this is a copy of the author's accepted manuscript of the paper. Minor changes may have been made to the text and certain details of the figures during the proof stage.

This document is stored on the NERC Open Research Archive at http://nora.nerc.ac.uk/20728/ and a copy of the final published article can be found at http://dx.doi.org/10.1038/NGEO1635 


\section{Extensive dissolution of live pteropods in the Southern}

\section{Ocean}

4 Bednaršek $\mathrm{N}_{1}$, Tarling $\mathrm{GA}_{1}{ }^{*}$, Bakker $\mathrm{DCE}_{2}$, Fielding $\mathrm{S}_{1}$, Jones $\mathrm{EM}_{3}$, Venables $\mathrm{HJ}_{1}$,

$5 \quad$ Ward $\mathrm{P}_{1}$, Kuzirian $\mathrm{A}_{4}$, Lézé $\mathrm{B}_{2}$, Feely RA $\mathrm{A}_{5}$, Murphy EJ $\mathrm{J}_{1}$

$6 \quad *$ corresponding author: gant@bas.ac.uk

7 1. British Antarctic Survey, Natural Environment Research Council, High Cross, Madingley Rd, Cambridge, CB3

$8 \quad 0 \mathrm{ET}, \mathrm{UK}$

9 2. School of Environmental Sciences, University of East Anglia, Norwich Research Park, Norwich NR4 7TJ, UK

10 3. Royal Netherlands Institute for Sea Research, P.O. Box 59, 1790 AB Den Burg, Texel, The Netherlands

11 4. Department of Geology and Geophysics, Woods Hole Oceanographic Institution, Woods Hole, Massachusetts, 12 USA

13 5. NOAA, Pacific Marine Environm Lab, Seattle, WA 98115 USA

14

15 The carbonate chemistry of the surface ocean is rapidly changing as a result of human activities ${ }^{1}$. In the Southern Ocean, aragonite (a metastable form of calcium carbonate with rapid dissolution kinetics) may become undersaturated $\left(\Omega_{\mathrm{A}}<1\right)$ in the upper layers by $2050^{2}$. This places at risk aragonite-shelled organisms such as euthecosome pteropods, which can dominate surface water communities in polar regions ${ }^{3}$. We provide field evidence that Southern Ocean pteropods are already showing signs of dissolution. Conditions where $\Omega_{\mathrm{A}} \approx 1$, caused by mixing of upwelled deep-water with surface water containing anthropogenic $\mathrm{CO}_{2}$, were found within $200 \mathrm{~m}$ of the surface. We extracted live specimens of the pteropod Limacina helicina antarctica from these undersaturated surface waters, as well as from supersaturated regions elsewhere, and compared their shell structure under SEM. Laboratory 
incubations with a range of $\Omega_{\mathrm{A}}$ saturation levels were carried out for up to $14 \mathrm{~d}$. Severe levels of shell dissolution were observed in the undersaturated region but not elsewhere. 8 days of incubation in $\Omega_{\mathrm{A}}$ 0.94-1.12 produced similar levels of dissolution. Both deep-water upwelling and $\mathrm{CO}_{2}$ absorption by surface waters is likely to increase as a result of human activities ${ }^{2,4}$, making upper ocean regions where aragonite is undersaturated more widespread.

Aragonite skeletons and tests are important components of the oceanic carbon system because they contribute a significant fraction of the global flux of particulate calcium carbonate $\left(\mathrm{CaCO}_{3}\right)$ settling to the ocean floor ${ }^{5}$. They are especially important in the short term buffering of the ocean absorption of anthropogenic $\mathrm{CO}_{2}{ }^{6,7}$. The surface ocean is generally saturated with respect to aragonite $\left(\Omega_{\mathrm{A}}>1\right)$ but the level of saturation decreases with depth. The point at which $\Omega_{\mathrm{A}}$ falls below 1 is called the saturation horizon, and this generally occurs around $1000 \mathrm{~m}$ but has shoaled by between 40 and $200 \mathrm{~m}$ as a direct consequence of the uptake of anthropogenic $\mathrm{CO}_{2}{ }^{2,8}$. Dissolution of shelled organisms mainly occurs when $\Omega$ falls below 1 but it has also been found in pteropods incubated in conditions where $\Omega_{\mathrm{A}}$ was $\approx 1^{9,10}$.

\section{There are already reports of surface waters occasionally being undersaturated with} respect to aragonite, including those of the Arctic Basin in 2008 after extensive melting of sea-ice ${ }^{11}$ and along the California continental shelf after seasonal upwelling of deep-water ${ }^{1}$. South of the polar front in the Southern Ocean, winter cooling and strong persistent winds are believed to be responsible for the ventilation of deeper waters to the surface, resulting in a natural decrease of carbonate ions of approximately $25 \%(35 \mu \mathrm{mol} / \mathrm{kg})$ relative to summer ${ }^{12}$. When combined with 
increases in anthropogenic $\mathrm{CO}_{2}$, ocean models predict that the Southern Ocean will begin to experience widespread aragonite undersaturation in surface waters after the year $2050^{2,13}$.

Euthecosome pteropods are amongst a small number of taxa that make their shells principally from aragonite. The effects of $\Omega_{\mathrm{A}}$ undersaturation on pteropods have mainly been investigated by laboratory incubations under enhanced partial pressures of $\mathrm{CO}_{2}\left(\mathrm{pCO}_{2}\right)$, simulating future atmospheric $\mathrm{CO}_{2}$ scenarios. Pteropods have been found to exhibit shell malformations ${ }^{14}$, lower rates of $\mathrm{CaCO}_{3}$ precipitation ${ }^{15}$ and dissolution of the shell exterior ${ }^{2}$. Effects have also been described on dead specimens collected in deep sediment traps ${ }^{16}$, where shells exposed to aragonite undersaturation had an opaque and pitted appearance. Byrne et al. ${ }^{9}$ demonstrated that sinking dead pteropods dissolved rapidly as they dropped below the saturation horizon. Feely et al. ${ }^{10}$ further found that dissolution in dead specimens starts at $\Omega_{\mathrm{A}}$ levels at or just below 1 across a range of North Pacific pteropod communities. Until the present study, such effects have not been documented on live animals extracted directly from the natural environment.

Sampling was carried out in the Scotia Sea, located in the Atlantic Sector of the Southern Ocean, where the strong flow of the Antarctic Circumpolar Current (ACC) is constricted in width. It is a physically dynamic region where deep water upwelling occurs $^{17}$ and eddies from frontal regions are frequently encountered ${ }^{18}$. The interaction of strong ACC flows coupled with bottom topography leads to greater micronutrient availability and hence extensive phytoplankton blooms downstream of topographic features $^{19,20}$. 
78 Live pteropods from this region were collected in January and February 2008 during cruise JR177 on RRS James Clark Ross as part of the British Antarctic Survey

Discovery 2010 program. Water sampling and depth-discrete net-catches of mesozooplankton to $400 \mathrm{~m}$ were done along a south to north transect within the Scotia

Sea (Fig. 1). The saturation horizon for aragonite was $1000 \mathrm{~m}$ across the majority of the transect. However, at station $\mathrm{Su} 9\left(52.6^{\circ} \mathrm{S}, 39.1^{\circ} \mathrm{W}\right)$, there was a notable incursion of waters with low $\Omega_{\mathrm{A}}$ values (minimum of 0.997 ) into layers above $400 \mathrm{~m}$ (Fig. 2).

Limacina helicina antarctica dominates mesozooplankton biomass in a number of Southern Ocean regions where it is the principle calcifying organism ${ }^{21}$. It is most commonly found above $400 \mathrm{~m}$ depth, particularly concentrating in the layers between $200 \mathrm{~m}$ and the surface ${ }^{3}$. It has life-cycle that can last upwards of 2 years, in which time it grows to $1 \mathrm{~cm}$ in shell diameter ${ }^{21}$. Analysis was carried out on both freshly caught material preserved directly upon collection and on specimens that were incubated under manipulated $\mathrm{CO}_{2}$ levels $\left(375\right.$ to 750 parts per million at $4^{\circ} \mathrm{C}$ ) in order to establish a response index. All freshly-caught and incubated specimens were preserved in $70 \%$ ethanol. Subsequently, they were treated to dehydrate shell-layers and to remove the periostracum (Fig. 3) so that the state of the underlying shell matrix could be examined using SEM.

Different degrees of dissolution were identified in incubated shells of live pteropods (see supplementary information). We categorised them into three main levels according to the degree of encroachment upon the upper prismatic layer and into the upper shell layer (Fig. 4). Specimens were scored blind and then correlated back to 
102 the experimental conditions. Incubations in which even only a slight degree of

103 undersaturation was experienced for $8 \mathrm{~d}\left(\Omega_{\mathrm{A}} 0.94-1.12, \mathrm{pCO}_{2}\right.$ of $\left.675 \mu \mathrm{atm}\right)$ was

104 sufficient to cause substantial dissolution of the shell matrix relative to the

105 supersaturated control $\left(\Omega_{\mathrm{A}} 1.62-1.78\right.$, Fig. 5). We then examined freshly caught

106 material, preserved directly upon collection, for signs of such shell dissolution.

107

108 L. helicina antarctica juveniles were found at all sampling stations, with northern

109 stations $\left(<57^{\circ} \mathrm{S}\right)$ containing higher abundances $\left(7.2 \times 10^{4}\right.$ to $3.4 \times 10^{4}$ ind. $\left.\mathrm{m}^{-2}\right)$ than

110 those to the south $\left(>57^{\circ} \mathrm{S} ; 2.9 \times 10^{2}\right.$ to $1.9 \times 10^{3}$ ind. $\left.\mathrm{m}^{-2}\right)$. At station Su9, we found $L$.

111 helicina antarctica juvenile specimens contained all three levels of dissolution.

112 Juveniles from other stations only contained small patches of the least severe level of

113 dissolution (Figs. 2, 5), probably caused by $\Omega_{\mathrm{A}}$-undersaturated microenvironments

114 close to the exterior surface resulting from the remineralisation of organic matter ${ }^{22}$.

115

116 Dissolution of live specimens from Su9 was apparent over the entirety of their shells

117 as opposed to just the inner whorls or the growing edge. This indicates firstly that the

118 periostracum (the outer organic layer) provides little if any protection to the

119 underlying shell matrix. If it did so, then parts where the periostracum is thinnest, e.g.

120 at the growing edge, would have been more affected. Secondly, dissolution must have

121 occurred recently, else it would have only been apparent on the oldest, inner whorls

122 and not at the newly deposited growing parts of the shells. We conclude that the

123 observed dissolution was principally a physico-chemical response to the carbonate

124 chemistry conditions in a body of water inhabited for the last 4 to $14 \mathrm{~d}$. The

125 dissolution response is similar to that found in dead specimens incubated at $\Omega_{\mathrm{A}} \approx 1$

126 reported by Byrne et al. ${ }^{9}$ and Feely et al. ${ }^{10}$ underlining the fact that live specimens 
127 have little to protect themselves from the effects of $\Omega_{\mathrm{A}}$ undersaturation. Furthermore,

128 in both live and dead specimens, it is apparent that dissolution can occur rapidly even

129 when in just close proximity to the aragonite saturation horizon.

131 Regions of upwelling that bring the saturation horizon close to the surface are likely

132 to be repeated through much of the Southern Ocean and are not a modern

133 phenomenon ${ }^{12}$. These deep-waters probably came into contact with the atmosphere

134 around 1000 years ago and so are unlikely to contain any anthropogenic $\mathrm{CO}_{2}$. Mixing

135 with surface waters will normally increase $\Omega_{\mathrm{A}}$ to above saturation levels but increases

136 in surface concentrations of $\mathrm{CO}_{2}$ will reduce the effect of this dilution. At station $\mathrm{Su} 9$,

137 an $\Omega_{\mathrm{A}}$ of around 1 was observed up to a depth of about $200 \mathrm{~m}$ despite mixing with

138 surface water. Calculations of the effect of anthropogenic carbon mixing down from

139 surface waters (see supplementary information) showed a reduction of $\Omega_{\mathrm{A}}$ values of

140 approximately 0.1 relative to pre-industrial values. Station Su9 was a site of

141 comparatively high phytoplankton biomass $\left(60 \text { to } 90 \mathrm{mg} \mathrm{C} \mathrm{m}^{-3}\right)^{20}$. However DIC

142 levels below $100 \mathrm{~m}$ were similar to another site with similar water mass properties but

143 low phytoplankton biomass ${ }^{20}$, indicating that extensive remineralization had not taken

144 place and the carbon export had not significantly lowered values of $\Omega_{\mathrm{A}}$. Therefore, the

145 primary causes of low $\Omega_{\mathrm{A}}$ values observed in this instance were mainly from the

146 addition of anthropogenic $\mathrm{CO}_{2}$ in surface waters mixing with upwelled deep-water.

148 Climate models project a continued intensification in Southern Ocean winds

149 throughout the $21^{\text {st }}$ century if atmospheric $\mathrm{CO}_{2}$ continues to increase ${ }^{4}$. In turn, this

150 will increase wind-driven upwelling and potentially make instances of deep-water,

151 under-saturated in aragonite penetrating into the upper mixed layers more frequent. 
152 Simultaneously, rising atmospheric concentrations of anthropogenic $\mathrm{CO}_{2}$ will

153 continue to reduce aragonite saturation levels in surface waters, particularly in polar

154 regions $^{12}$. Conditions such as observed at station $\mathrm{Su} 9$ are therefore likely to become

155 more common in the Southern Ocean, making shell-dissolution an increasing threat to

156 pteropod populations.

157

158 Pteropods do not necessarily die as a result of dissolution. Calcification of the inside

159 of the shell probably continues and, to some degree, counteracts the dissolution of the

160 exterior of the shell. Nevertheless, the observed rapidity of the dissolution response

161 means that, in the present instance, there would have been net loss of shell overall, as

162 reported in other experimental manipulations ${ }^{15}$. The main consequence of such loss of

163 shell is an increased vulnerability to predation and infection, which will in turn impact

164 other parts of the foodweb ${ }^{15}$. A drop in their population size will affect the ocean's

165 carbonate cycle given the important role of pteropods in balancing oceanic alkalinity

166 budgets $^{7}$. Rates of vertical carbon flux will also decline, as the pteropod shells

167 become less dense and less able to act as ballast for other particulate material ${ }^{23}$.

169 This report documents a dissolution response of live pteropods within their natural

170 environment as a result of exposure to waters where $\Omega_{\mathrm{A}} \approx 1$. The data validate the

171 prediction of a wide body of laboratory-based studies on the vulnerability of this

172 important taxon to the acidification of polar oceans $s^{2,14,24}$. The shallow aragonite

173 saturation horizon we observed was at least partially the result of oceanic absorption

174 of anthropogenic $\mathrm{CO}_{2}$ and demonstrates that the impact of ocean acidification is

175 already occurring in oceanic populations, long before some projected dates of $\Omega_{\mathrm{A}}$

176 undersaturation $^{12}$. Regional declines of pteropods populations may occur sooner than 
177 presently projected as areas of $\Omega_{\mathrm{A}}$ undersaturation in Southern Ocean surface waters

178 become more widespread.

179

180 Methods

181 Field sampling: Samples were collected along a south to north transect within the

182 Scotia Sea region of the Southern Ocean $\left(60^{\circ} \mathrm{S}\right.$ and $48^{\circ} \mathrm{W}$ to $50^{\circ} \mathrm{S} 34^{\circ} \mathrm{W}$, Fig. 1$)$ in

183 February 2008 on board the RRS James Clark Ross. Full-depth CTD casts and

184 plankton net samples were collected every 60 to $100 \mathrm{~km}$ along the transect. Water

185 samples were collected every $50 \mathrm{~m}$ down to $200 \mathrm{~m}$ depth and then every $200 \mathrm{~m}$ down

186 to $1000 \mathrm{~m}$ depth during each CTD cast. Juvenile L. helicina antarctica were collected

187 in the upper water column (0-400 m) with a vertically hauled motion compensated

188 Bongo net $\left(0.5 \mathrm{~m}^{2}, 100 \mu \mathrm{m}\right.$ and $200 \mu \mathrm{m}$ meshed nets $)$. Captured specimens were either

189 preserved immediately in $70 \%$ ethanol or used in incubation analyses.

190

191 Water analysis: Water samples were used for dissolved inorganic carbon (DIC) and

192 total alkalinity (TA) analysis following the Standard Operating Procedures for oceanic

$193 \mathrm{CO}_{2}$ measurements (30), detailed in Jones et al. ${ }^{20}$. A VINDTA (Versatile INstrument

194 for the Determination of Titration Alkalinity, Marianda, Kiel, Germany) was used to

195 measure DIC and TA, with a Certified Reference Material (CRM) analysed in

196 duplicate for DIC and TA at the beginning and end of each sample analysis day. The

197 concentration of DIC was determined using the principles of coulometric analysis ${ }^{25}$.

198 The accuracy of the DIC measurements was $2.4 \mu \mathrm{mol} \mathrm{kg}{ }^{-1}$ and the precision, $1.5 \mu \mathrm{mol}$

$199 \mathrm{~kg}^{-1}$. Analysis for TA was carried out by potentiometric titration with hydrochloric

200 acid to the carbonic acid end point ${ }^{26}$. The accuracy and precision of TA values was

$201 \quad 2.6 \mu \mathrm{mol} \mathrm{kg} \mathrm{kg}^{-1}$ and $1.0 \mu \mathrm{mol} \mathrm{kg}{ }^{-1}$ respectively. 
203 DIC and TA, alongside temperature, salinity, pressure and macronutrient

204 concentrations from all discrete samples, were used to calculate the remaining

205 carbonate chemistry parameters including total $\mathrm{pH}\left(\mathrm{pH}_{\mathrm{T}}\right)$ and $\Omega$ aragonite $\left(\Omega_{\mathrm{A}}\right)$. This

206 was done using the $\mathrm{CO}_{2}$ Sys programme ${ }^{27}$ with thermodynamic dissociation constants

207 for $\mathrm{K}_{1}$ and $\mathrm{K}_{2}$ by Mehrbach et al. ${ }^{28}$ and the re-fit by Dickson and Millero ${ }^{29}$.

209 Pteropod analysis: Before further analysis, captured pteropod specimens were

210 inspected to select only those that had not suffered mechanical damage during

211 capture. Two sets of control samples were taken to consider capture and incubation

212 effects - one immediately fixed post capture from an $\Omega_{\mathrm{A}}$ supersaturated region

213 (natural control), another after varying lengths of incubation in $\Omega_{\mathrm{A}}$ supersaturated

214 conditions $(\Omega=1.7 \pm 0.08$; incubation control). There was no evidence of the more

215 advanced stages of dissolution (levels II and III) in either the natural or incubation

216 control samples. Level I dissolution covered just under $10 \%$ of the surface area in the

217 natural control sample, and $56 \%$ of surface area in the incubation control, indicating

218 an incubation effect. Accordingly, dissolution levels II and III were given most weight

219 as indicators of dissolution when comparing incubated material with that taken

220 directly from the natural environment.

222 Incubations were carried out in $0.22 \mathrm{GF} / \mathrm{F}$ filtered seawater to remove bacteria and

223 held in 2 L blacked-out flasks through which was bubbled synthetic air containing one

224 of four different $\mathrm{CO}_{2}$ mixing ratios $\left(\mathrm{xCO}_{2}\right)$ (BOC Special Products): 375, 500, 750

225 and $1200 \mathrm{ppm}(\mu \mathrm{mol} / \mathrm{mol})$. Bubbling was stopped once water reached the correct $\mathrm{CO}_{2}$

226 mixing ratio and around 50 individuals (principally juveniles) were introduced to the 
227 flask, which was subsequently sealed, with head space kept to a minimum.

228 Incubations were run for between 4 and $14 \mathrm{~d}$, with water samples taken at the start

229 and end of each incubation to verify $\Omega_{\mathrm{A}}$ state (as above). Accordingly, each flask was

230 categorised into one of three $\Omega_{\mathrm{A}}$ states: supersaturated (1.1 to 1.8$)$, transitional (0.95-

231 1.1) or under-saturated ( 0.75 to 0.95$)$. All pteropods were preserved in $70 \%$ ethanol.

232

233 Preserved pteropod shells were prepared as detailed in Bednarsek et al. ${ }^{30}$. Firstly, 234 abiogenic crystal precipitates on the shell surface were removed with $6 \%$ hydrogen 235 peroxide $\left(\mathrm{H}_{2} \mathrm{O}_{2}\right)$, followed by a dehydration method including the use of 2,2-

236 dimethoxypropane (DMP) and 1,1,1,3,3,3-hexamethyldisilazane (HMDS). This

237 procedure was finely tuned to remove the precipitates without damaging any shell

238 layers. The overlying organic layer was then etched to expose the shell microstructure 239 for SEM analysis, using a JEOL JSM 5900LV at an acceleration voltage of $15 \mathrm{kV}$ and 240 a working distance of about $10 \mathrm{~mm}$. 15 to 20 SEM photographs were taken across the 241 shell surface area of each specimen in order to determine the proportion of the shell

242 surface covered by each level of dissolution. Each image was analysed using 243 customised image-segmentation software (EDISON software) which estimated the 244 extent of each dissolution level in each image. Images were combined to determine 245 overall coverage for each specimen. Detailed description and user-guidelines on the 246 procedure are given at

247 http://coewww.rutgers.edu/riul/research/code/EDISON/index.html.

\section{Acknowledgements}

250 This work was supported by the FAASIS (Fellowships in Antarctic Air-Sea-Ice 251 Science), a Marie Curie Early Stage Training Network awarded to NB. G.A.T., S.F. 
252

253

254

255

256

257

and P.W. carried out this work as part of the Ecosystems core-science programme at the British Antarctic Survey. G.A.T., P.W. and D.B. received further support during the analysis and synthesis stages from the pelagic consortium of the UK Ocean Acidification programme, funded by NERC, Defra and DECC (grant no.

NE/H017267/1). D. McCorkle and A. Cohen of Woods Hole Oceanographic

Institution helped develop a shell preparation method and commented on previous drafts of the manuscript. Image analysis was carried out at University of East Anglia with the assistance of Roberto Montagna. Sampling operations were supported by the officers and crew of the RRS James Clark Ross with net-sampling equipment support from Peter Enderlein of BAS.

\section{Author contributions}

G.A.T and D.C.E.B. conceived the project; N.B. carried out the fieldwork, with the assistance of G.A.T., S.F. and P.W.; E.M.J. and H.J.V. provided supporting environmental data; A.K. helped develop a method of shell preparation for SEM analysis; B.L. developed an image analysis method; G.A.T., N.B. and D.C.E.B cowrote the manuscript, with theoretical overviews provided by R.A.F. and all remaining authors commenting.

\section{Additional information}

The authors declare no competing financial interests. Supplementary information accompanies this paper on www.nature.com/naturegeoscience. Reprints and permissions information is available online at www.nature.com/reprints. Correspondence and requests for materials should be addressed to G.AT. 


\section{$278 \quad$ References}

279 1. Feely, R.A., Sabine, C.L., Hernandez-Ayon, J.M., Ianson, D. \& Hales, B.

280 Evidence for upwelling of corrosive "acidified" water onto the continental

281 shelf. Science 320, 1490-1492 (2008).

282 2. Orr, J.C. et al. Anthropogenic ocean acidification over the twenty-first century

283 and its impact on calcifying organisms. Nature 437, 681-686 (2005).

284 3. Hunt, B.P.V. et al. Pteropods in Southern Ocean ecosystems. Prog. Oceanogr.

$285 \quad 78,193-221(2008)$.

286 4. Le Quere, C. et al. Saturation of the Southern Ocean CO2 sink due to recent

287 climate change. Science 316, 1735-1738 (2007).

288 5. Fabry, V.J. Shell growth rates of pteropod and heteropod molluscs and

289 aragonite production in the open ocean: implications for the marine carbonate

$290 \quad$ system. J. Mar. Res. 48, 209-222 (1990).

291 6. Broecker, W.S. \& Takahashi, T. Neutralization of fossil fuel carbon dioxide

292 by marine calcium carbonate. in The fate of fossil fuel $\mathrm{CO}_{2}$ in the oceans (eds.

293 Andersen, N.R. \& Malahoff, A.) 213-241 (1977).

294 7. Betzer, P.R. et al. The oceanic carbonate system - a reassessment of biogenic

$295 \quad$ control. Science 226, 1074-1077 (1984).

296 8. Feely, R.A. et al. Impact of anthropogenic $\mathrm{CO}_{2}$ on the $\mathrm{CaCO}_{3}$ system in the 297 oceans. Science 305, 362-366 (2004).

298 9. Byrne, R.H., Acker, J.G., Betzer, P.R., Feely, R.A. \& Cates, M.H. Water 299 column dissolution of aragonite in the Pacific Ocean. Nature 312, 321-326 $300 \quad$ (1984).

301 10. Feely, R.A. et al. Winter-summer variations of calcite and aragonite saturation 
in the Northeast Pacific. Mar. Chem. 25, 227-241 (1988).

303 11. Yamamoto-Kawai, M., McLaughlin, F.A., Carmack, E.C., Nishino, S. \&

304 Shimada, K. Aragonite undersaturation in the Arctic Ocean: Effects of ocean

305 acidification and sea ice melt. Science 326, 1098-1100 (2009).

306 12. McNeil, B.I. \& Matear, R.J. Southern Ocean acidification: A tipping point at

$307450 \mathrm{ppm}$ atmospheric $\mathrm{CO}_{2}$. P. Natl. Acad. Sci. USA 105, 18860-18864 (2008).

308 13. Steinacher, M., Joos, F., Frolicher, T.L., Plattner, G.K. \& Doney, S.C.

309 Imminent ocean acidification in the Arctic projected with the NCAR global

$310 \quad$ coupled carbon cycle-climate model. Biogeosciences 6, 515-533 (2009).

311 14. Comeau, S., Jeffree, R., Teyssie, J.L. \& Gattuso, J.P. Response of the Arctic

312 pteropod Limacina helicina to projected future environmental conditions. Plos

$313 \quad$ One 5(2010).

314 15. Comeau, S., Gorsky, G., Alliouane, S. \& Gattuso, J.P. Larvae of the pteropod

315 Cavolinia inflexa exposed to aragonite undersaturation are viable but shell-

316 less. Mar. Biol. 157, 2341-2345 (2010).

317 16. Roberts, D. et al. Interannual pteropod variability in sediment traps deployed

318 above and below the aragonite saturation horizon in the Sub-Antarctic

319 Southern Ocean. Polar Biol. 34, 1739-1750 (2011).

320 17. Heywood, K.J., Garabato, A.C.N. \& Stevens, D.P. High mixing rates in the 321 abyssal Southern Ocean. Nature 415, 1011-1014 (2002).

322 18. Kahru, M., Mitchell, B.G., Gille, S.T., Hewes, C.D. \& Holm-Hansen, O.

323 Eddies enhance biological production in the Weddell-Scotia confluence of the 324 Southern Ocean. Geophys. Res. Lett. 34, L14603. DOI:

$325 \quad$ 10.1029/2007GL030430. (2007).

326 19. Park, J., Ohb, I.-S., Kim, H.-C. \& Yoo, S. Variability of SeaWiFs chlorophyll- 
a in the southwest Atlantic sector of the Southern Ocean: Strong topographic effects and weak seasonality. Deep-Sea Res Pt. I 57, 604-620 (2010).

20. Jones, E., Bakker, D., Venables, H. \& Watson, A. Dynamic seasonal cycling of inorganic carbon downstream of South Georgia, Southern Ocean. Deep-Sea Res. Pt. II, doi: 10.1016/j.dsr2.2011.08.001 (2012).

332 21. Bednarsek, N., Tarling, G., Fielding, S. \& Bakker, D. Population dynamics

22. Jansen, H., Zeebe, R.E. \& Wolf-Gladrow, D.A. Modeling the dissolution of settling $\mathrm{CaCO} 3$ in the ocean. Global Biogeochem. Cycles 16(2002).

23. Francois, R., Honjo, S., Krishfield, R. \& Manganini, S. Factors controlling the flux of organic carbon to the bathypelagic zone of the ocean. Glob. Biogeochem. Cycles 16(2002).

24. Fabry, V.J., McClintock, J.B., Mathis, J.T. \& Grebmeier, J.M. Ocean acidification at high latitudes: the bellweather. Oceanography 22, 160-171

343 25. Johnson, K.M., Sieburth, J.M., Williams, P.J.L. \& Brandstrom, L. Coulometric total carbon dioxide analysis for marine studies - automation and

346 26. Dickson, A.G. An exact definition of total alkalinity and a procedure for the estimation of alkalinity and total inorganic carbon from titration data. Deep-

$348 \quad$ Sea Res. 28, 609-623 (1981).

349 27. Lewis, E. \& Wallace, D.W.R. CO2SYS-Program developed for the CO2 system calculations. in Carbon Dioxide Information and Analysis Centre. 
352 28. Mehrbach, C., Culberson, C.H., Hawley, J.E. \& Pytkowicz, R.M.

353 Measurement of the apparent dissociation constants of carbonic acid in

354 seawater at atmospheric pressure Limnol. Oceanogr. 18, 897-907 (1973).

355 29. Dickson, A.G. \& Millero, F.J. A comparison of the equilibrium constants for

356 the dissociation of carbonic acid in seawater media. . Deep-Sea Res. 34(1987).

357 30. Bednarsek, N. et al. Description and quantification of pteropod shell

358 dissolution: a sensitive bioindicator of ocean acidification. Global Change

359 Biol. 18, 2378-2388 (2012).

360 
Figure Legends

Figure 1: Scotia Sea showing sampling station positions and frontal positions at time of sampling. Dynamic height contours were used to determine the location of the following fronts: $S B$ Southern Boundary, SACCF Southern Antarctic Circumpolar Current Front, south and north edge of Polar Front (S-PF, N-PF). 15\% ice cover represented by blue shading.

Figure 2: Vertical profiles of $\Omega_{\mathrm{A}}$ across the Scotia Sea (upper) and corresponding dissolution levels in live juvenile Limacina helicina antarctica (lower). $\mathrm{N}$ is the number of individuals analysed per station. Horizontal bars denote mean proportional shell area per dissolution level across all specimens, error bars represent 1 SD. Level I dissolution was significantly higher in $\mathrm{Su} 9$ specimens compared to all other stations (Mann-Whitney rank sum test, $\mathrm{T}=778,20$ and $35 \mathrm{df}, \mathrm{P}<0.001$ ). Su9 was also the only station in which level II and III dissolution was observed.

Figure 3: SEM section of the shell of Limacina helicina antartica showing the organic layer (periostracum), prismatic layer and crossed-lamellar matrix of aragonite crystals.

Figure 4: SEM images of juvenile Limacina helicina antarctica (from which the periostracum has been removed) showing different levels of dissolution. (a,b) intact animal without any indications of dissolution; (c) level I: the upper prismatic layer slightly dissolved and the aragonite crystals of the crossed-lamellar matrix starting to become exposed; (d) level II: the prismatic layer partially or completely missing and the cross-lamellar matrix almost completely exposed; (e,f) level III: the 
386 crossed-lamellar matrix showing signs of dissolution across large areas of the shell,

387 the shell becoming more porous [High resolution images are available in

388 Supplementary Information].

389

390 Figure 5: Average (SD) proportion of different dissolution levels in live juvenile

391 Limacina helicina antarctica from the natural environment and ship-board

392 incubations. Supersaturated refers to $\Omega_{\mathrm{A}}>1$.1, transitional, $0.95-1.1$ and

393 undersaturated, 0.75 to 0.95 . $\mathrm{N}$ refers to numbers of specimens analysed. Vertical bars

394 denote mean proportional shell area per dissolution level, error bars represent 1 SD.

$39514 \mathrm{~d}$ incubations in undersaturated conditions caused a significant increase in level III

396 dissolution compared to all other groupings (Kruskal-Wallis 1-way ANOVA, $\mathrm{H}=$

$39751.7,4 \mathrm{df}, \mathrm{P}<0.001)$. Amounts of level II and III dissolution were statistically

398 indistinguishable between Su9 and $8 \mathrm{~d}$ transitional incubations. 


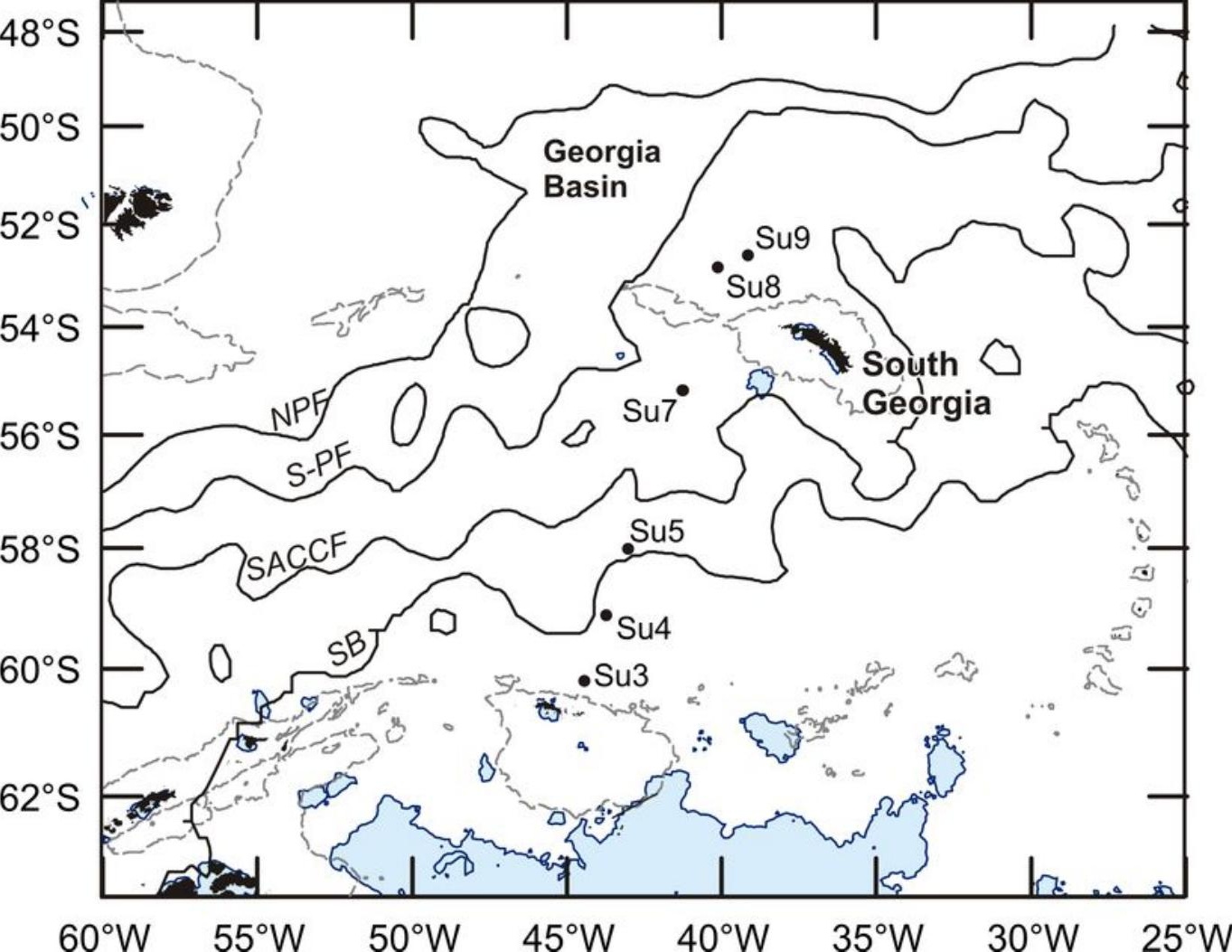




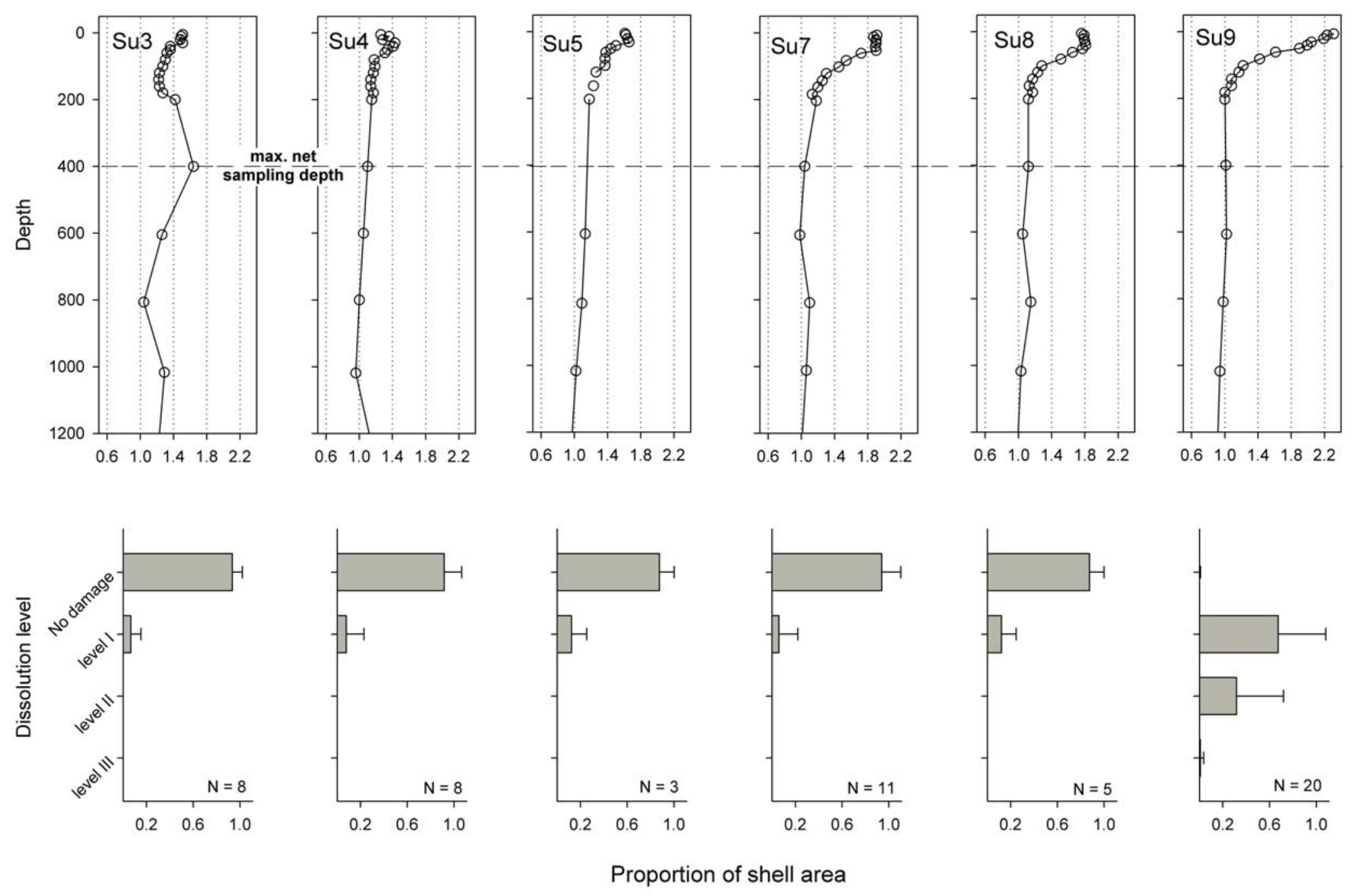


Figure 3

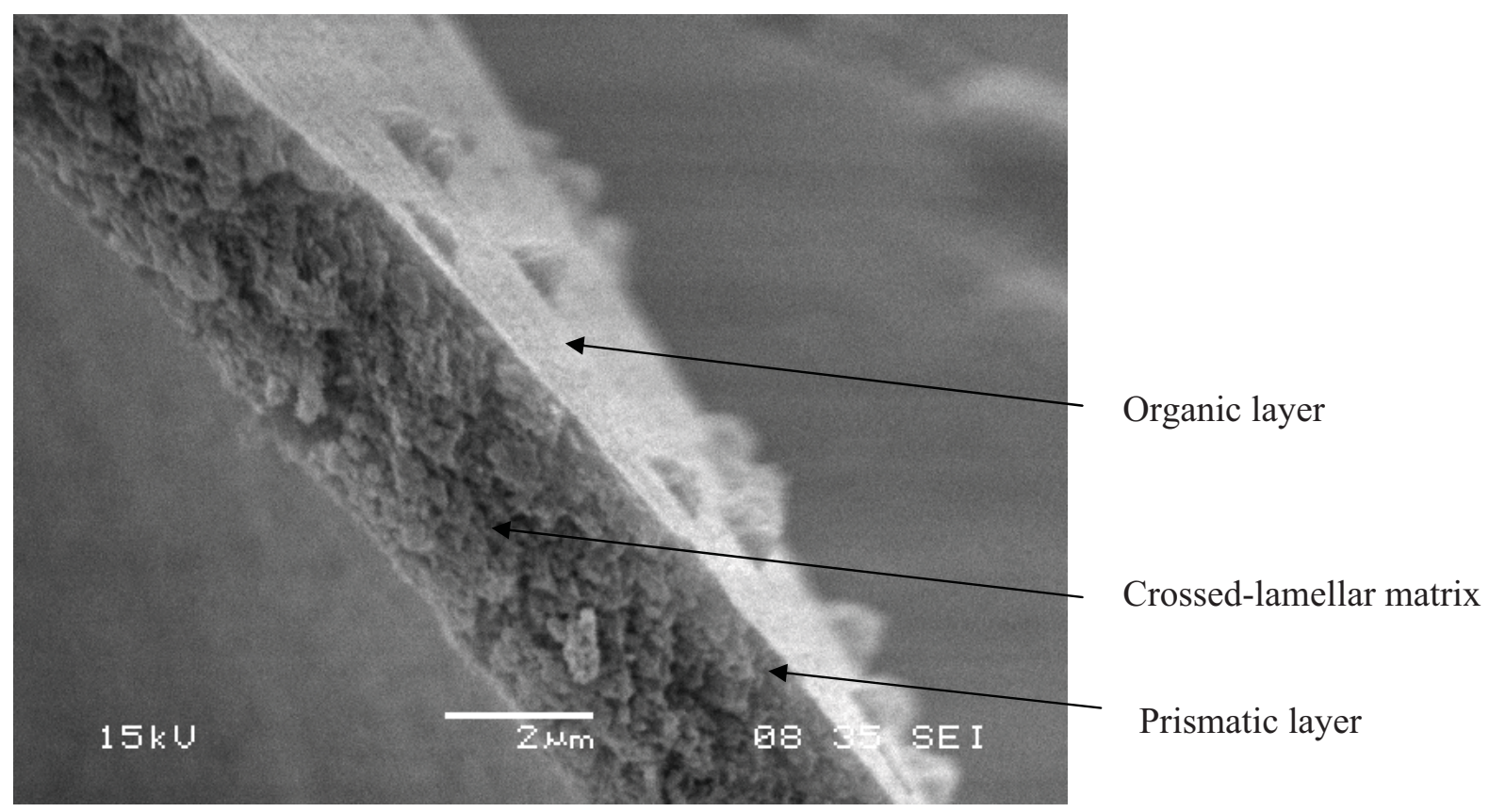


Figure 4
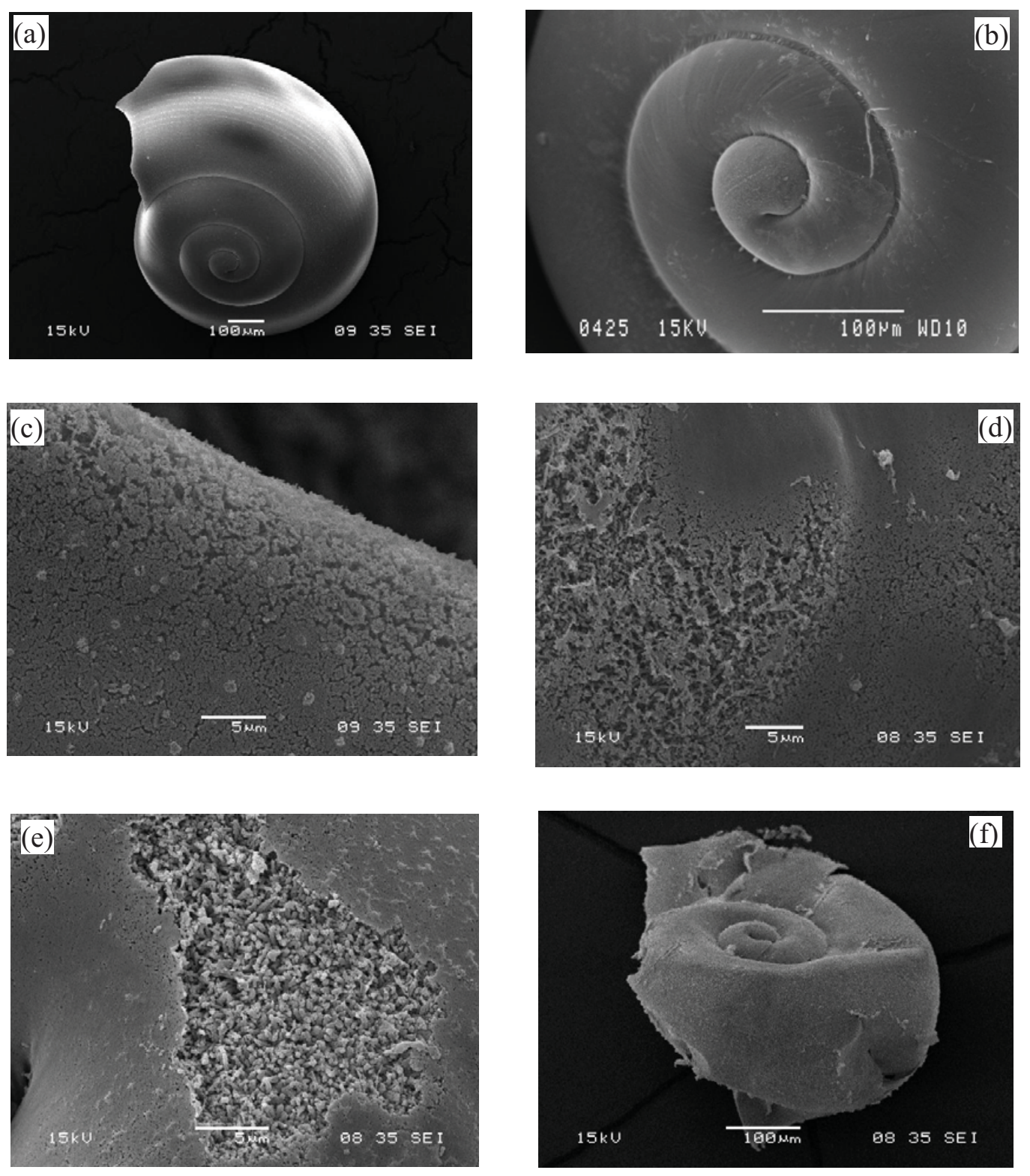


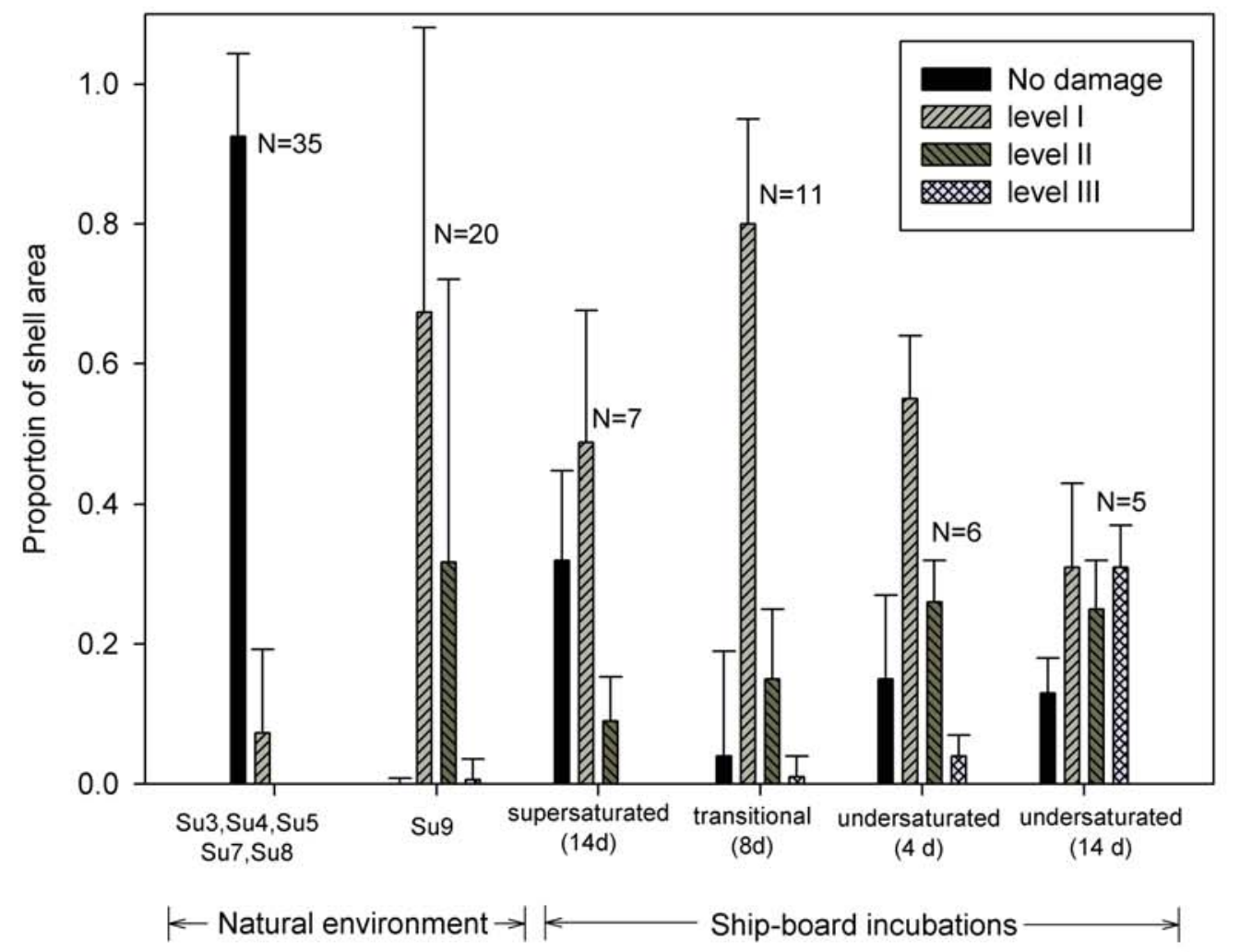




\section{Supplementary Information:}

\section{Extensive dissolution of live pteropods in the Southern Ocean}

Bednaršek $\mathrm{N}_{1}$, Tarling $\mathrm{GA}_{1}$ *, Bakker $\mathrm{DCE}_{2}$, Fielding $\mathrm{S}_{1}$, Jones $\mathrm{EM}_{3}$, Venables $\mathrm{HJ}_{1}$, Ward $\mathrm{P}_{1}$, Kuzirian $\mathrm{A}_{4}$, Lézé $\mathrm{B}_{2}$, Feely RA $\mathrm{R}_{5}$, Murphy EJ $\mathrm{J}_{1}$

*corresponding author: gant@bas.ac.uk

1. British Antarctic Survey, Natural Environment Research Council, Madingley Rd, Cambridge, CB3 0ET, UK

2. School of Environmental Sciences, University of East Anglia, Norwich Research Park, Norwich NR4 7TJ, UK

3. Royal Netherlands Institute for Sea Research, P.O. Box 59, 1790 AB Den Burg, Texel, The Netherlands

4. Department of Geology and Geophysics, Woods Hole Oceanographic Institution, Woods Hole, Massachusetts, USA

5. NOAA, Pacific Marine Environm Lab, Seattle, WA 98115 USA

\section{Sensitivity study of the influence of anthropogenic carbon on surface water} aragonite saturation state: To establish if anthropogenic $\mathrm{CO}_{2}$ altered the carbonate chemistry at station $\mathrm{Su} 9\left(52.6^{\circ} \mathrm{S}, 39.1^{\circ} \mathrm{W}\right)$, a sensitivity study was conducted assuming that the changes in carbonate chemistry result only from the uptake of anthropogenic $\mathrm{CO}_{2}$ while the ocean was temporarily invariant in all relevant water parameters, following the approach of Yamamoto-Kawai et al. (2009, Science 326:1098-1100).

An end-member mixing calculation was used to assess the extent of surface water mixing downwards. This was based on physical oceanographic measurements taken at Su9 (Venables et al. 2012, Deep-Sea Res II 59-60: 14-24). At this site, the winter mixed layer (WML) reached a maximum depth of $140 \mathrm{~m}$, while unmodified Circumpolar Deep Water (CDW) reached a minimum depth of around $400 \mathrm{~m}$ (at which depth $\mathrm{pCO}_{2}$ was 571 $\mu \mathrm{atm})$. Using mixing rates calculated from the salinity profile, and not taking into account any further biological effects, the percentage ratio of WML to CDW water at $204 \mathrm{~m}$ (above which depth most pteropods were concentrated) was $58 \%$ to $42 \%$. Dissolved inorganic carbon was assumed to mix conservatively following salinity mixing ratios. These calculations agreed with the penetration of CFCs below the mixed layer in data collected from the region on a separate research cruise (Brown, unpublished). Accordingly, the addition of $104 \mu \mathrm{atm}$ of $\mathrm{pCO}_{2}$ to surface waters resulting from anthropogenic $\mathrm{CO}_{2}$ would reduce to $60.3 \mu \mathrm{atm}$ at $204 \mathrm{~m}$ (and to $0 \mu$ atm at $400 \mathrm{~m}$ where there is no penetration of surface water).

The remaining carbonate chemistry parameters for present day and preindustrial situations were calculated using $\mathrm{sysCO}_{2}$ (http://cdiac.ornl.gov/ftp/cp2sys) for given input conditions of temperature, salinity, pressure and nutrient concentrations (Supplementary Tables 1 and 2). Comparison of the tables show that, in preindustrial conditions, $\Omega_{\mathrm{A}}$ values at, for example, $182 \mathrm{~m}$ would have been above 1.167, as opposed to a present day value of 0.997 . 


\begin{tabular}{|c|c|c|c|c|c|c|c|c|c|c|c|c|}
\hline \multirow[t]{2}{*}{ Depth } & \multirow[t]{2}{*}{ Salinity } & \multirow[t]{2}{*}{$\begin{array}{c}\text { Phosph } \\
\text { ate }\end{array}$} & \multirow[t]{2}{*}{ Silicate } & \multirow[t]{2}{*}{ Temp } & \multirow[t]{2}{*}{ TA } & \multirow[t]{2}{*}{ TC } & \multirow[t]{2}{*}{$\mathrm{pCO}_{2}$} & \multirow[t]{2}{*}{ pH_T } & \multicolumn{3}{|c|}{$\begin{array}{l}\text { CARBONATE } \\
\text { IONS }\end{array}$} & \multirow{2}{*}{$\begin{array}{c}\text { Omega } \\
\text { arag- } \\
\text { onite }\end{array}$} \\
\hline & & & & & & & & & $\mathrm{CO}_{2}$ & $\mathrm{HCO}_{3}^{-}$ & $\mathrm{CO}_{3}{ }^{2-}$ & \\
\hline$(\mathrm{m})$ & & $\begin{array}{c}(\mu \mathrm{mol} \\
\left.\mathrm{kg}^{-1}\right)\end{array}$ & $\begin{array}{c}(\mu \mathrm{mol} \\
\left.\mathrm{kg}^{-1}\right)\end{array}$ & $\left({ }^{\circ} \mathrm{C}\right)$ & $\begin{array}{c}(\mu \mathrm{mol} \\
\left.\mathrm{kg}^{-1}\right)\end{array}$ & $\begin{array}{c}(\mu \mathrm{mol} \\
\left.\mathrm{kg}^{-1}\right)\end{array}$ & 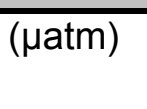 & & \multicolumn{3}{|c|}{$\left(\mu \mathrm{mol} \mathrm{kg}{ }^{-1}\right)$} & \\
\hline 82 & 33.91 & 1.82 & 28.56 & 1.24 & 2290.0 & 2165.2 & 385 & 8.044 & 23 & 2047 & 95 & 1.418 \\
\hline 102 & 33.99 & 1.94 & 44.16 & 0.00 & 2286.9 & 2184.8 & 430 & 7.997 & 27 & 2075 & 82 & 1.220 \\
\hline 121 & 34.03 & 1.99 & 49.14 & -0.27 & 2287.4 & 2190.4 & 442 & 7.984 & 28 & 2083 & 80 & 1.174 \\
\hline 142 & 34.10 & 2.07 & 55.57 & -0.22 & 2295.7 & 2210.7 & 490 & 7.943 & 31 & 2106 & 74 & 1.081 \\
\hline 162 & 34.18 & 2.14 & 61.12 & 0.10 & 2299.1 & 2213.4 & 496 & 7.938 & 31 & 2108 & 74 & 1.083 \\
\hline 182 & 34.23 & 2.19 & 64.21 & 0.36 & 2301.2 & 2227.3 & 553 & 7.894 & 34 & 2125 & 68 & 0.997 \\
\hline 203 & 34.31 & 2.24 & 68.44 & 0.73 & 2308.8 & 2234.2 & 563 & 7.888 & 34 & 2131 & 69 & 1.000 \\
\hline 400 & 34.60 & 2.28 & 87.35 & 1.72 & 2336.8 & 2255.6 & 571 & 7.880 & 34 & 2149 & 73 & 1.014 \\
\hline
\end{tabular}

Supplementary Table 1: Carbon chemistry parameters derived using Matlab CO2sys, total pH scale, Mehrbach refit by Dickson and Millero using measurements made at station $\mathrm{Su} 9\left(52.6^{\circ} \mathrm{S}, 39.1^{\circ} \mathrm{W}\right)$, Scotia Sea, Jan 2008. 


\begin{tabular}{|c|c|c|c|c|c|c|c|c|c|c|c|c|}
\hline \multirow[t]{2}{*}{ Depth } & \multirow[t]{2}{*}{ Salinity } & \multirow[t]{2}{*}{$\begin{array}{c}\text { Phosph } \\
\text { ate }\end{array}$} & \multirow[t]{2}{*}{ Silicate } & \multirow[t]{2}{*}{ Temp } & \multirow[t]{2}{*}{ TA } & \multirow[t]{2}{*}{ TC } & \multirow[t]{2}{*}{$\mathrm{pCO}_{2}$} & \multirow[t]{2}{*}{ pH_T } & \multicolumn{3}{|c|}{$\begin{array}{c}\text { CARBONATE } \\
\text { IONS }\end{array}$} & \multirow{2}{*}{$\begin{array}{c}\text { Omega } \\
\text { arag- } \\
\text { onite }\end{array}$} \\
\hline & & & & & & & & & $\mathrm{CO}_{2}$ & $\mathrm{HCO}_{3}{ }^{-}$ & $\mathrm{CO}_{3}{ }^{2-}$ & \\
\hline$(\mathrm{m})$ & & $\begin{array}{c}(\mu \mathrm{mol} \\
\left.\mathrm{kg}^{-1}\right)\end{array}$ & $\begin{array}{l}(\mu \mathrm{mol} \\
\left.\mathrm{kg}^{-1}\right)\end{array}$ & $\left({ }^{\circ} \mathrm{C}\right)$ & $\begin{array}{c}(\mu \mathrm{mol} \\
\left.\mathrm{kg}^{-1}\right)\end{array}$ & $\begin{array}{c}(\mu \mathrm{mol} \\
\left.\mathrm{kg}^{-1}\right)\end{array}$ & 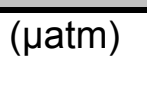 & & \multicolumn{3}{|c|}{$\left(\mu \mathrm{mol} \mathrm{kg}^{-1}\right)$} & \\
\hline 82 & 33.91 & 1.82 & 28.56 & 1.24 & 2290.0 & 2117.2 & 279 & 8.169 & 17 & 1978 & 123 & 1.825 \\
\hline 102 & 33.99 & 1.94 & 44.16 & 0.00 & 2286.9 & 2145.5 & 324 & 8.108 & 20 & 2021 & 104 & 1.535 \\
\hline 121 & 34.03 & 1.99 & 49.14 & -0.27 & 2287.4 & 2153.0 & 336 & 8.092 & 21 & 2032 & 100 & 1.468 \\
\hline 142 & 34.10 & 2.07 & 55.57 & -0.22 & 2295.7 & 2178.5 & $\begin{array}{r}38 \\
4\end{array}$ & 8.040 & 24 & 2064 & 90 & 1.324 \\
\hline 162 & 34.18 & 2.14 & 61.12 & 0.10 & 2299.1 & 2186.4 & 405 & 8.020 & 25 & 2073 & 88 & 1.285 \\
\hline 182 & 34.23 & 2.19 & 64.21 & 0.36 & 2301.2 & 2203.5 & 459 & 7.969 & 28 & 2095 & 80 & 1.167 \\
\hline 203 & 34.31 & 2.24 & 68.44 & 0.73 & 2308.8 & 2215.5 & 487 & 7.947 & 30 & 2108 & 78 & 1.132 \\
\hline 400 & 34.60 & 2.28 & 87.35 & 1.72 & 2336.8 & 2255.6 & 571 & 7.880 & 34 & 2149 & 73 & 1.014 \\
\hline
\end{tabular}

Supplementary Table 2: Carbon chemistry parameters derived using Matlab CO2sys, total pH scale, Mehrbach refit by Dickson and Millero using measurements made at station $\mathrm{Su} 9\left(52.6^{\circ} \mathrm{S}, 39.1^{\circ} \mathrm{W}\right)$, Scotia Sea, Jan 2008 , but assuming preindustrial atmospheric $\mathrm{pCO}_{2}$ levels. 


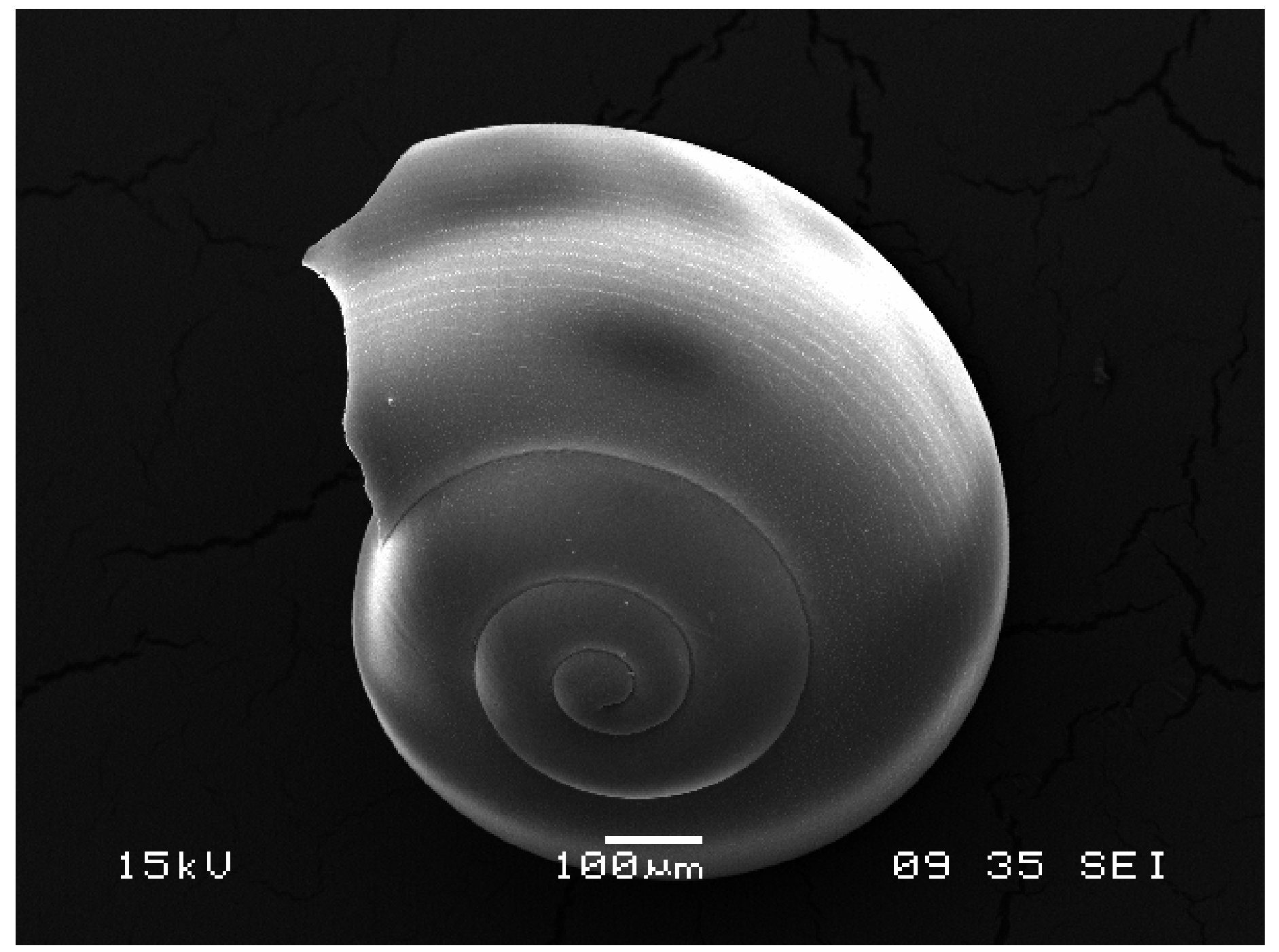

Supplementary Figure 1. High resolution SEM images of juvenile Limacina helicina antarctica showing intact animal without any indications of dissolution. 


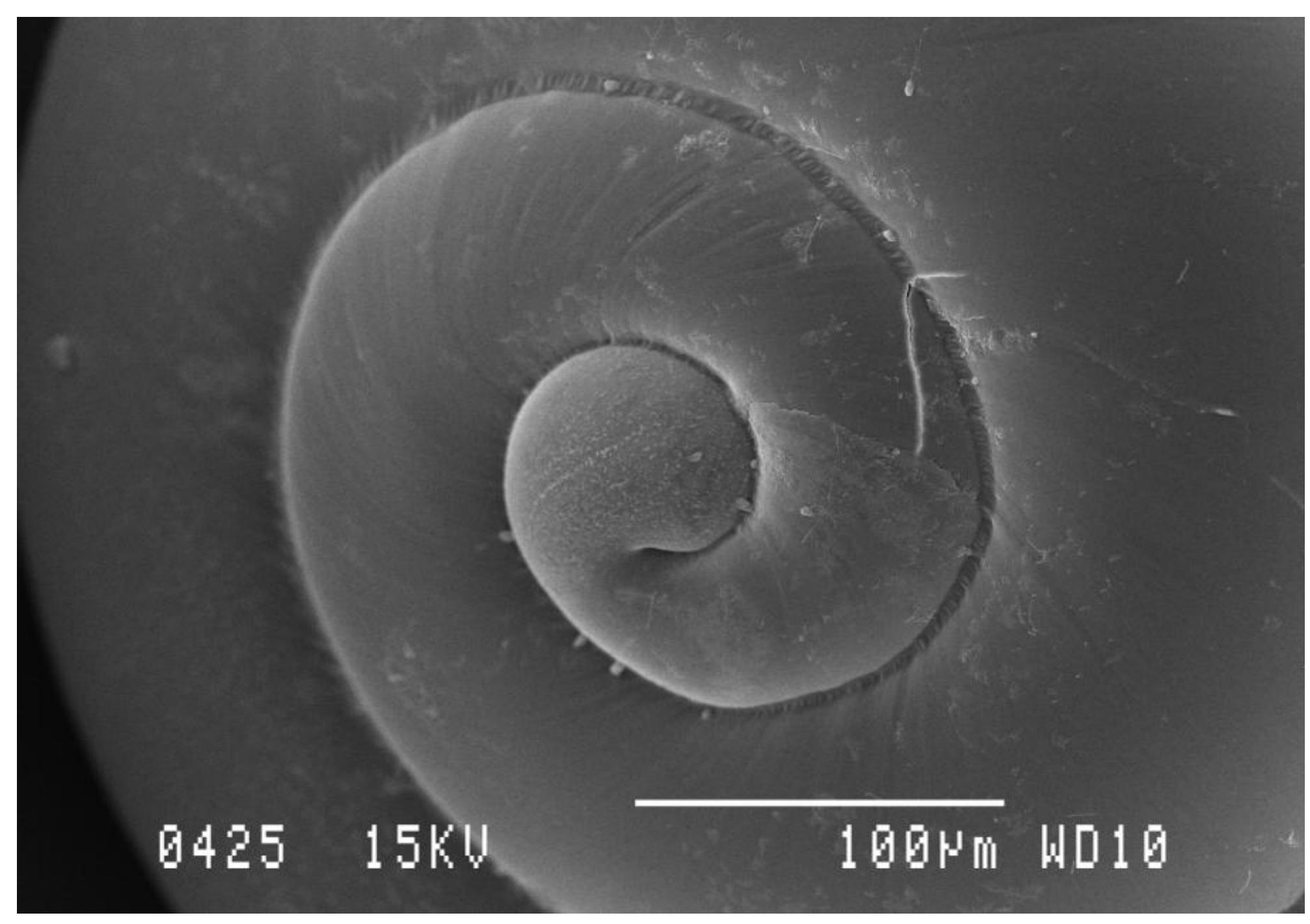

Supplementary Figure 2. High resolution SEM images of juvenile Limacina helicina antarctica showing intact animal without any indications of dissolution. 


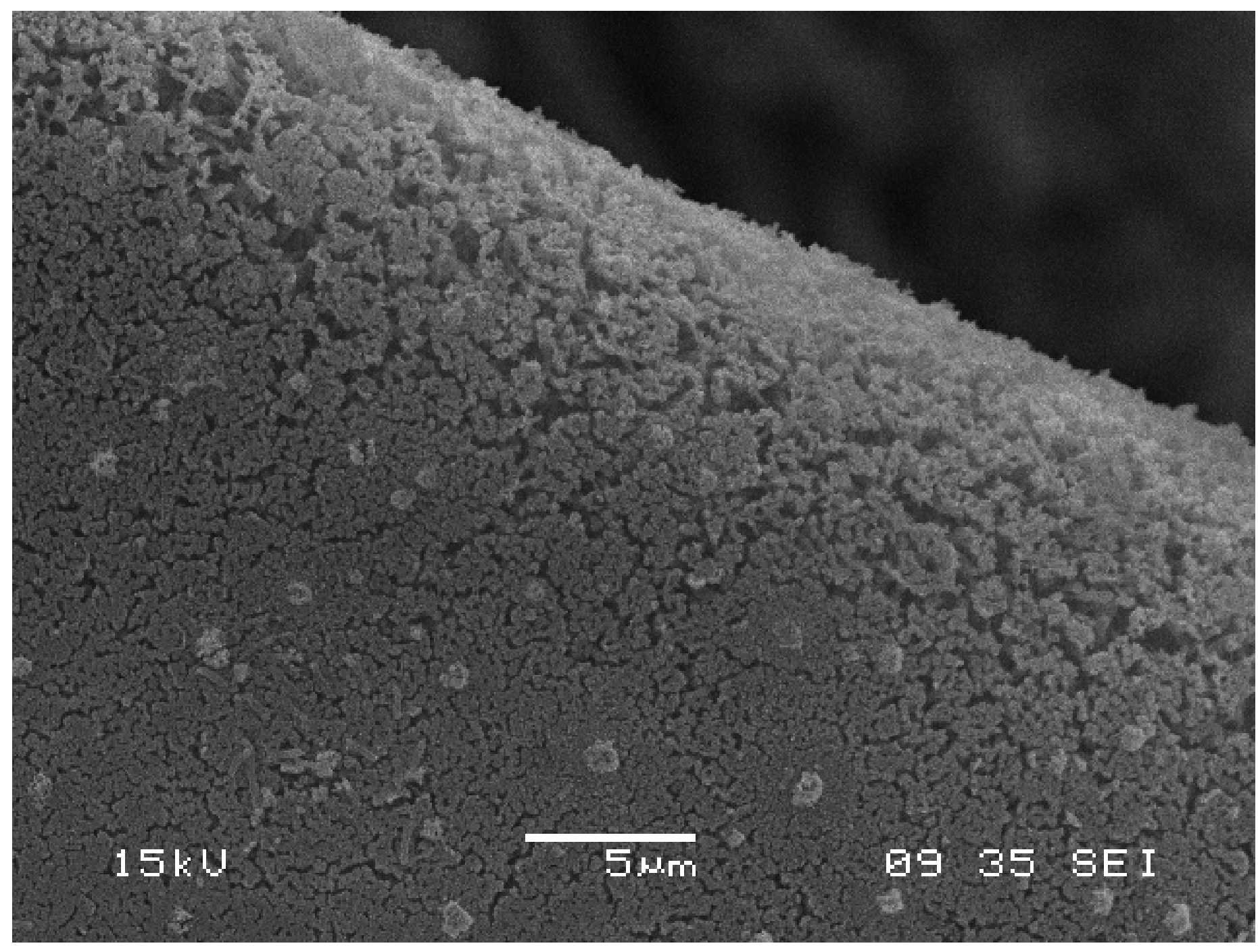

Supplementary Figure 3. High resolution SEM images of juvenile Limacina helicina antarctica showing level I dissolution: the upper prismatic layer slightly dissolved. 


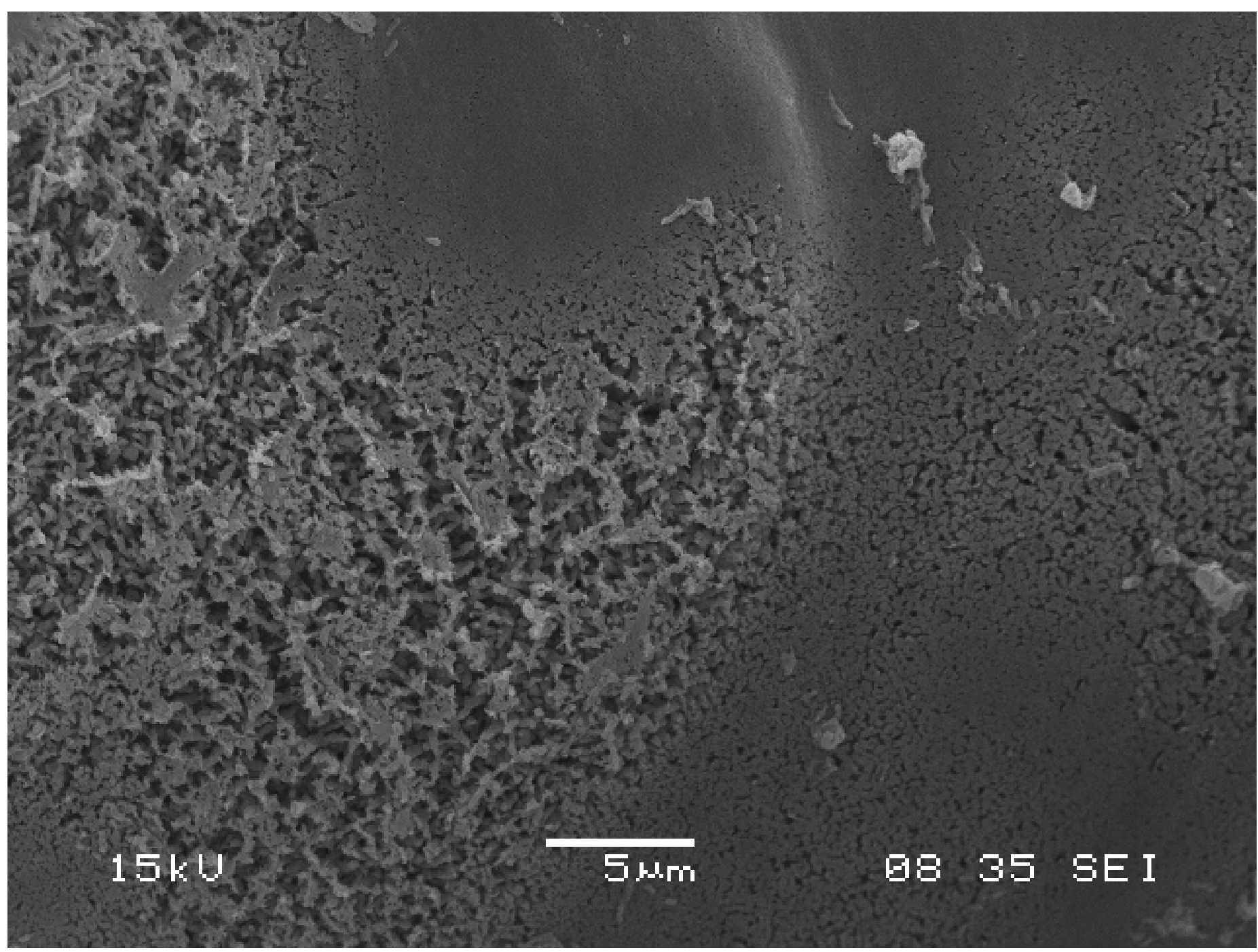

Supplementary Figure 4. High resolution SEM images of juvenile Limacina helicina antarctica showing level II dissolution: the prismatic layer partially or completely missing and the cross-lamellar matrix partially exposed with increasing porosity in the upper crystalline layer. 


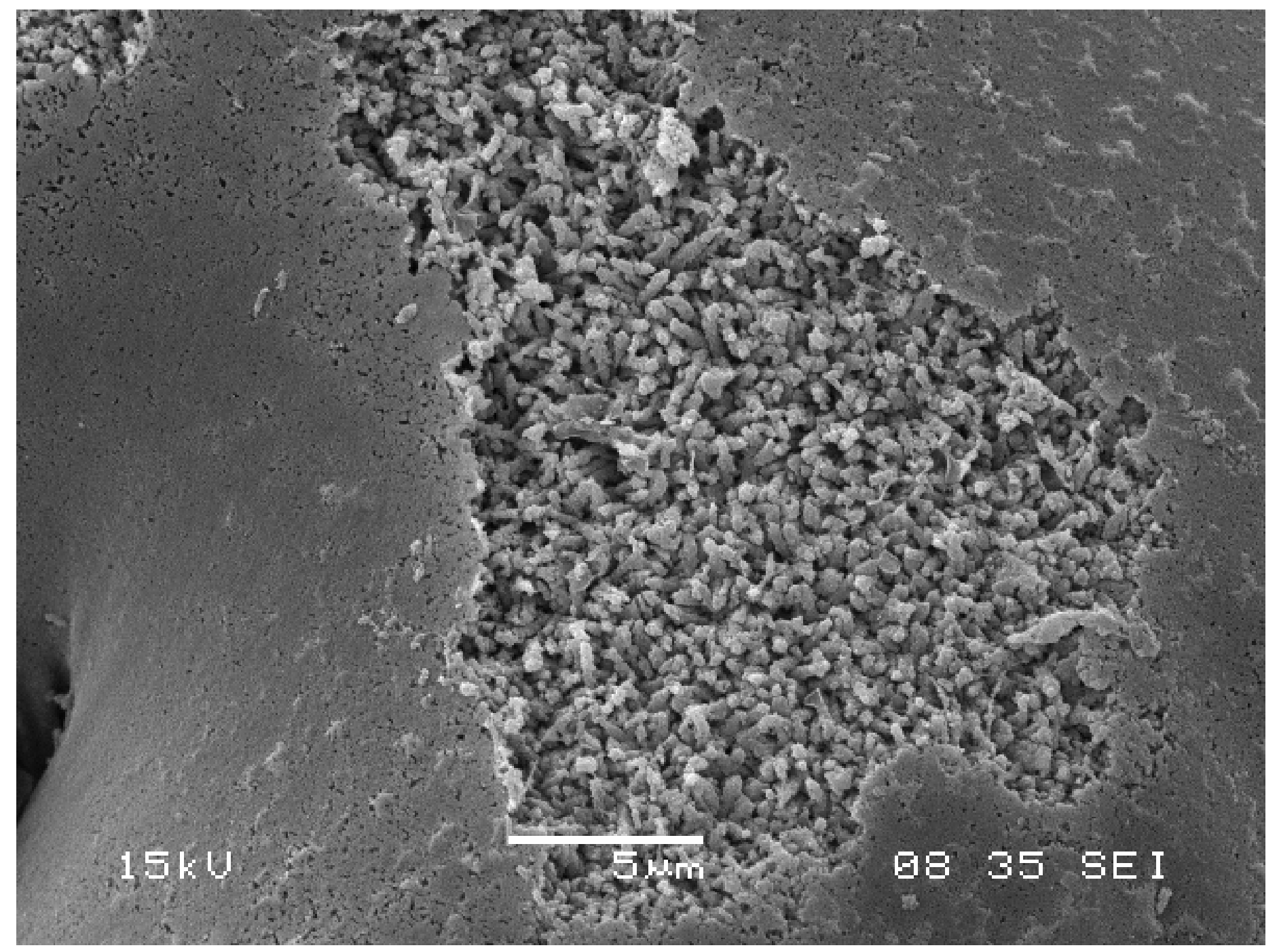

Supplementary Figure 5. High resolution SEM images of juvenile Limacina helicina antarctica showing level III dissolution: the crossedlamellar matrix showing signs of dissolution across large areas of the shell, the shell becoming more fragile due to fragmentation. Crystals transform from elongated rods to being more 'cauliflower-like' in appearance. 


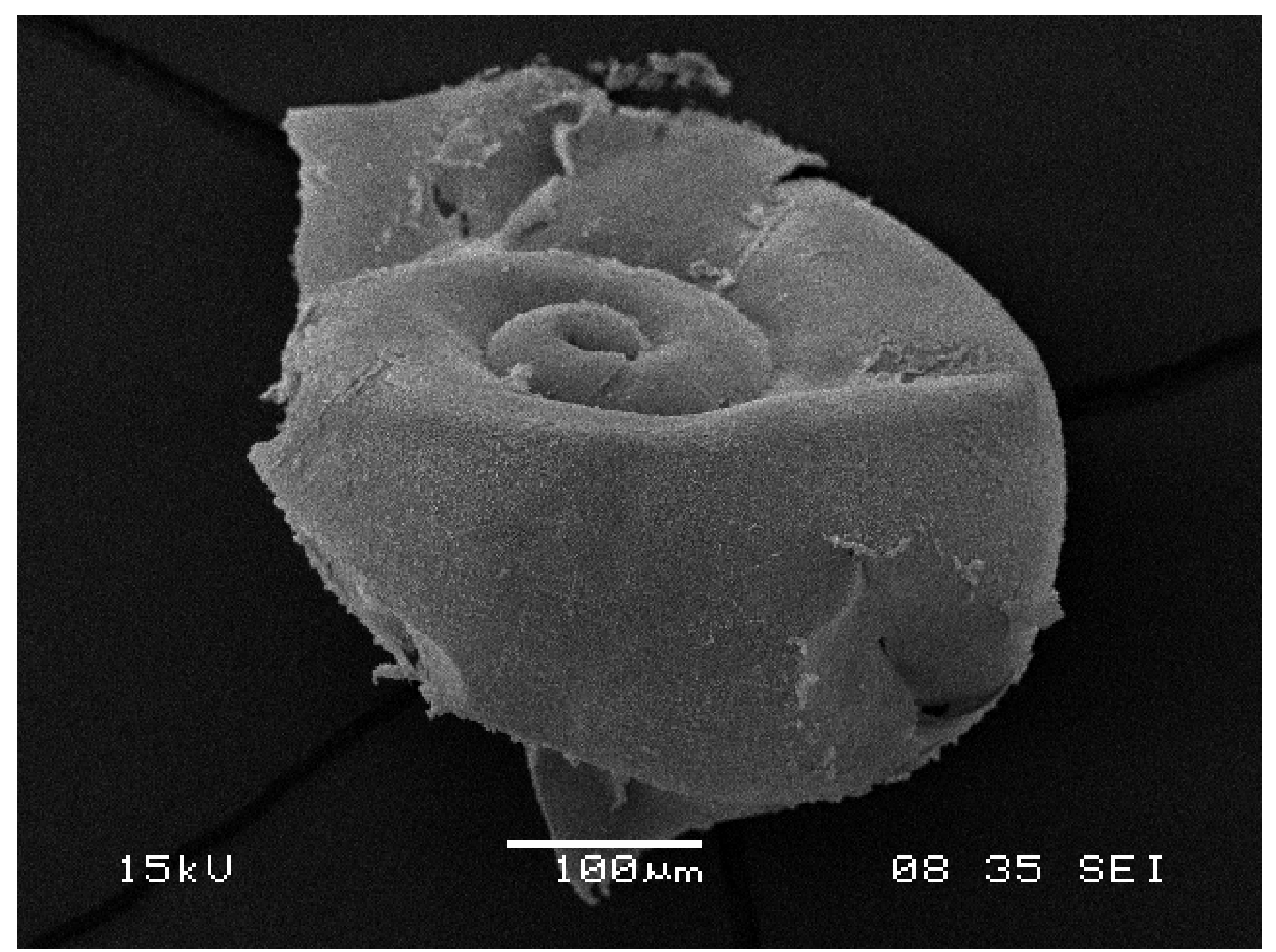

Supplementary Figure 6. High resolution SEM images of juvenile Limacina helicina antarctica showing level III dissolution: the crossedlamellar matrix showing signs of dissolution across large areas of the shell, the shell becoming more fragile due to fragmentation. 